\title{
РОЗМІРНІ ОЗНАКИ КОГОРТ ПРОВІДНИХ ЛІСОУТВОРЮВАЛЬНИХ ВИДІВ ЛІВОБЕРЕЖНОГО ПОЛІССЯ УКРАЇНИ
}

\author{
Скляр В. Г., Мельничук С. Д.
}

\section{ВСТУП}

У рослинному покриві Землі лісам належить провідна роль за зайнятою площею і за значенням ${ }^{1,2,3}$. Важливою складовою частиною функціонування лісових угруповань є природне відновлення ${ }^{4,5,6,7}$. Воно репрезентує складний, довготривалий та багатоетапний процес, протягом якого у особин нового покоління лісоутворювальних видів відбуваються якісні та кількісні зміни, що забезпечують послідовний перехід цих рослин з одного ярусу лісу в наступний і досягнення ними рівня деревостану.

Взаємодії та перетворення, визначальні для проходження кожного окремо взятого етапу відновлення, а також для формування у лісоутворювальних видів безперервного потоку поколінь, який забезпечує стійке існування та функціонування лісових фітоценозів, досі остаточно не з'ясовані. Їх вивчення $\epsilon$ актуальною науковою проблемою, яка має велике теоретичне та практичне значення і для вирішення потребує застосування класичних і сучасних біологічних методів. Серед них високим рівнем інформативності вирізняються еколого-ценотичний підхід та комплексний популяційний аналіз.

У територіальному аспекті дослідження природного відновлення та з'ясування зазначених проблемних питань $є$ особливо актуальними для

1 Шеляг-Сосонко Ю.Р. Ліси України: біорізноманітність та збереження. Украӥнський ботанічний журнал. 2001. Т. 58. № 5. С. 519-529.

2 Шеляг-Сосонко Ю.Р. Екологічне та соціальне значення лісів. Менеджмент охоронних лісів Украӥни. Київ : Фитосоциоцентр, 2003. С. 10-23.

3 Ситник К.М. Збереження та відтворення лісових багатств України. Украйнський ботанічний журнал. 2003. Т. 60. № 1. С. 3-5.

${ }^{4}$ Пастернак П.С., Романов НВ. Возобновление равнинных лесов Украинской ССР. Возобновление леса. Москва : Колос, 1975. С. 214-215.

${ }^{5}$ Санников С.Н., Санникова Н.С. Экология естественного возобновления сосны под пологом леса. Москва :Наука, 1985. 149 с.

${ }^{6}$ Connel J.H. Some processes affecting the species composition in forest gaps. Ecology. 1989. Vol. 70. № 3. P. 560-562.

${ }^{7}$ Ward J.S., Worthley T.E. Forest regeneration handbook. USA Forest N., E. Area. 2004. 44 p. 
регіонів, у яких ліси відіграють провідну роль у формуванні природних комплексів та мають велике еколого-стабілізуюче, созологічне та господарське значення. В Україні до таких територій належить Полісся, зокрема його Лівобережна частина.

Успішність природного відновлення значною мірою визначається розмірними параметрами особин, які формують материнський деревостан та репрезентують молоде покоління лісоутворювальних видів. Загалом розмір рослинних організмів значною мірою у зв'язку з прикріпленим способом життя $\epsilon$ дуже важливою базовою характеристикою. Однозначного визначення розміру рослин не існує, хоча 3 ним тісно пов'язано багато властивостей, зокрема тривалість життя, місце, що займає вид у біогеоценозі, роль у харчових ланцюгах екосистеми ${ }^{8}$. Розділ ботаніки, який вивчає розмір рослин кількісними методами, називають фітоморфометрією або морфометрією. Морфометрія рослин знайшла широке застосування в популяційних дослідженнях. До важливих характеристик належить розмірна структура популяцій ${ }^{910}$.

Лісова геоботаніка та лісознавство $є$ науковими напрямами, у яких морфометричні дослідження також знайшли досить широке впровадження і є важливими як з теоретичної, так і практичної точок зору. У зазначеному аспекті до піонерних належать роботи М.В. Третьякова ${ }^{11}$. Сучасні автори розглядають розмірні ознаки деревостанів як інтегральне відображення відмінностей у рості рослин ${ }^{12}$.

У процесі росту й розвитку особин молодого покоління відбувається суттєва, а саме в десятки і сотні разів, зміна їхніх розмірів, зокрема загальної фітомаси, висоти. Це веде до формування в межах однієї популяції внутрішньопопуляційних груп рослин, які мають свої біолого-екологічні особливості, відрізняються розташуванням основних фотосинтезуючих органів у різних ярусах лісу, а коренів - у різних грунтових горизонтах. Екосистемна роль таких

${ }^{8}$ McElwain J.C. Beerling D.J., Woodward F.I. Fossil plants and global warming at the triassic-jurassic boundary. Science. 1999. Vol. 285. № 5432. P. 1386-1390.

${ }^{9}$ Skliar V.G. The dimensional characteristics of the middle undergrowth Quercus robur in forests of Novgorod-Sivers'k Polissia (Ukraine). European Applied Sciences. 2013. № 7. P. 23.

${ }^{10}$ Skliar V., Sherstuk M. Size structure of phytopopulations and its quantitative evaluation. Eureka: Life Sciences. 2016. № 1. P. 9-15.

11 Третьяков Н.В. Закон единства в строении насаджений. Новая деревня. Москва ; Ленинград, 1927. 113 с.

12 Кофман Г.Б., Кузьмичев В.В. Размерная структура древостоев: универсальность и единство. Эколого-географические аспекты лесообразовательного процесса. Красноярск : Институт леса Сибирского отделения РАН, 2009. С. 91-93. 
внутрішньопопуляційних утворень також істотно різниться. За очевидності зазначених фактів це питання $є$ мало дослідженим. У зв'язку з цим розроблена система поділу популяцій деревних рослин на внутрішньопопуляційні структурні групи, а саме когорти. В іiі основу покладена прийнята в лісівництві методика реєстрації підросту і дерев, доповнена оцінкою розміру рослин, їх онтогенетичного стану й положення в архітектоніці лісової екосистеми.

\section{1. Методи досліджень}

У складі популяцій провідних лісоутворювальних видів виділені такі когорти ${ }^{13}$.

1) Сходи (seedling). Це рослини, що з'явилися навесні поточного року. Для особин видів із надземним проростанням характерною ознакою $є$ наявність сім'ядоль, а 3 підземним проростанням первинних лускоподібних листків. Ці рослини зазвичай розміщуються у пригрунтовому шарі нижче основного намету листового покриву трав'яно-чагарничкового ярусу. В деяких із фітоценозів сходи знаходяться на рівні трав'яно-чагарничкового або мохового ярусу. У загальноприйнятій системі дискретного опису онтогенезу вони відповідають категорії “p”.

2) Проростки (plantlet). Переважно це рослини 1-3 року життя. Вони мають справжні листки, переважно ювенільного типу. Залежно від виду дерев вони здебільшого знаходяться під наметом листового покриву трав'яно-чагарничкового ярусу або охоплюють його нижню частину. За онтогенетичним станом це збірна група: до неї можуть входити особини категорії “p” і ювенільні особини категорії “j”.

3) Дрібний підріст (small undergrowth). Це когорта рослин, яка розміщена повністю у трав'яно-чагарничковому ярусі лісового фітоценозу. Особини мають висоту до 50 см, рідше - до 60-70 см. Коренева система їх поверхнева. Календарний вік становить від 3-5 років до десятків років. За онтогенетичним станом це ювенільні або імматурні особини, а в несприятливих екологічних умовах ще й так звані квазісенільні («торчки»).

4) Середній підріст (middle undergrowth). Рослини цієї когорти «виходять» із трав'яно-чагарничкового ярусу і «вбудовуються» у ярус підліску. Особини середнього підросту переважно охоплюють висотний діапазон від 0,5 м до 2,5 м. За календарним віком вони дуже

${ }^{13}$ Скляр В.Г., Злобін Ю.А. Внутрішньопопуляційна структура та методика іiі вивчення у деревних лісоутворюючих видів. Чорноморский ботанічний журнал. 2013. T. 9. № 3. С. 316-329. 
piзні: 10-11 і більше років. Це переважно імматурні, рідше віргінільні рослини. Всі вони вирізняються досить швидким ростом у висоту.

5) Великий підріст (large undergrowth). Особини великого підросту знаходяться у ярусі підліску. Порівняно з дрібним і середнім підростом їхня коренева система розміщена у глибших шарах грунту. Здебільшого це рослини висотою 2,5-8,0 м. Їхній календарний вік зазвичай більше 20-25 років (залежно від виду).

6) Молоді дерева верхнього ярусу лісу (young trees). Вони знаходяться у стані «вбудовування» у ярус деревостану лісового угруповання. Це віргінільні особини, дещо нижчі за основний намет деревостану.

7) Генеративні дерева верхнього ярусу лісу (mature tree). Цю когорту складають рослин $\mathrm{g}_{1}-\mathrm{g}_{3}$-станів. До неї також належать субсенільні особини, які ще зберігають репродуктивну здатність. Висота й вік дерев визначаються їх видовою належністю.

Когорти 1-6 за загальної характеристики розглядались як молоде покоління того чи іншого лісоутворювального виду, а когорти 3-5 - як його підріст. Кожна 3 когорт як внутрішньопопуляційна структурна група відрізняється певними відмінностями у стані особин, які входять до іiї складу, що є підставою для застосування для них комплексного популяційного аналізу. Цей підхід був використаний у дослідженнях, спрямованих на з'ясування особливостей та закономірностей природного відновлення провідних лісоутворювальних видів Лівобережного Полісся України (Pinus sylvestris L., Quercus robur L., Acer platanoides L., Betula pendula Roth., Populus tremula L.).

Загальний перелік розмірних показників, що оцінювалися у когорт цих видів у процесі морфометричного аналізу, представлений у табл. 1-3. Під час вивчення розмірних ознак середнього та великого підростів, а також більш дорослих дерев враховувались три основні морфопараметри (загальна висота особин, діаметр стовбура та співвідношення між ними (HDR)). Для молодих та генеративних дерев діаметр стовбура вимірювався на висоті 1,3 м, а у всіх когорт підросту - на рівні кореневої шийки. Вивчення стану дрібного підросту супроводжувалося визначенням 18-22 морфопараметрів, а сходів та проростків - 5-11.

Загалом детальне вивчення розмірних ознак когорт провідних лісоутворювальних видів Лівобережного Полісся України здійснено у найбільш поширених та типових для регіону досліджень угрупованнях, що належать до 24 синтаксонів у ранзі груп асоціацій та 42 синтаксонів у ранзі асоціацій (табл. 4). 
Таблиця 1

Статичні метричні морфопараметри

\begin{tabular}{|c|c|c|}
\hline Назва морфопараметра & $\begin{array}{c}\text { Умовні } \\
\text { позначення }\end{array}$ & Одиниця виміру \\
\hline Загальна маса рослини & $\mathrm{W}$ & $\Gamma$ \\
\hline Загальна фітомаса листків & WL & $\Gamma$ \\
\hline Висота рослини & $\mathrm{h}$ & $\mathrm{cm}$ \\
\hline Діаметр стовбура & $\mathrm{d}$ & $\mathrm{cm}$ \\
\hline Вік особини & $\mathrm{Ag}$ & років \\
\hline Фітомаса стовбура & Wst & $\Gamma$ \\
\hline Загальна площа поверхні листків & A & $\mathrm{cm}^{2}$ \\
\hline Загальна кількість листків & $\mathrm{NL}$ & ШТ. \\
\hline Фітомаса одного листка & $w l$ & $\Gamma$ \\
\hline Площа одного листка & $a$ & $\mathrm{~cm}^{2}$ \\
\hline $\begin{array}{c}\text { Кількість хвоїнок на } 5 \text { см } \\
\text { верхівкового пагону }\end{array}$ & Oxv & шт. \\
\hline Кількість мутовок & Nmut & Шт. \\
\hline Кількість бічних пагонів & NB & ШТ. \\
\hline $\begin{array}{c}\text { Кількість бічних пагонів першого } \\
\text { порядку галуження }\end{array}$ & $\mathrm{B}_{1}$ & шт. \\
\hline $\begin{array}{c}\text { Кількість бічних пагонів першого } \\
\text { порядку галуження в мутовці }\end{array}$ & B_mut & шт. \\
\hline Довжина головного кореня & $\mathrm{L}_{\mathrm{kr}}$ & $\mathrm{CM}$ \\
\hline
\end{tabular}

Таблиця 2

Статичні алометричні морфопараметри

\begin{tabular}{|c|c|c|}
\hline Назва морфопараметра & $\begin{array}{c}\text { Умовні позначення } \\
\text { та розрахункові формули } \\
\text { морфопараметрів }\end{array}$ & $\begin{array}{c}\text { Одиниця } \\
\text { виміру }\end{array}$ \\
\hline $\begin{array}{c}\text { Співвідношення площі листової поверхні } \\
\text { та фітомаси надземної частини (площа } \\
\text { листків на одиницю фітомаси) }\end{array}$ & $\mathrm{LAR}=\mathrm{A} / \mathrm{W}$ & $\mathrm{cm}^{2} / \Gamma$ \\
\hline $\begin{array}{c}\text { Співвідношення маси листків та } \\
\text { фітомаси надземної частини } \\
\text { (фотосинтетичне зусилля) }\end{array}$ & $\mathrm{LWR}=\mathrm{WL} / \mathrm{W}$ & $\Gamma / \Gamma$ \\
\hline $\begin{array}{l}\text { Співвідношення площі листової } \\
\text { поверхні та діаметра стовбура }\end{array}$ & $\mathrm{ADR}=\mathrm{A} / \mathrm{d}$ & $\mathrm{cm}^{2} / \mathrm{MM}$ \\
\hline $\begin{array}{c}\text { Співвідношення висоти та фітомаси } \\
\text { надземної частини (відносний приріст) }\end{array}$ & $\mathrm{HWR}=\mathrm{h} / \mathrm{W}$ & $\mathrm{cm} / \Gamma$ \\
\hline $\begin{array}{l}\text { Співвідношення висоти рослин } \\
\text { та діаметра їх стовбура }\end{array}$ & $\mathrm{HDR}=\mathrm{h} / \mathrm{d}$ & $\mathrm{cm} / \mathrm{cm}$ \\
\hline $\begin{array}{c}\text { Співвідношення кількості бічних } \\
\text { пагонів першого порядку та висоти } \\
\text { рослини (кількість бінних пагонів на } \\
\text { одиницю висоти) }\end{array}$ & $\mathrm{B} / \mathrm{h}=\mathrm{B}_{1} / \mathrm{h}$ & шт./см \\
\hline $\begin{array}{c}\text { Співвідношення висоти рослини } \\
\text { та довжини головного кореня }\end{array}$ & $\mathrm{h} / \mathrm{L}_{\mathrm{kr}}$ & $\mathrm{cm} / \mathrm{cm}$ \\
\hline
\end{tabular}


Таблиця 3

Динамічні метричні морфопараметри

\begin{tabular}{|c|c|c|}
\hline Назва морфопараметра & $\begin{array}{c}\text { Умовні позначення } \\
\text { та розрахункові формули } \\
\text { морфопараметрів }\end{array}$ & $\begin{array}{c}\text { Одиниці } \\
\text { виміру }\end{array}$ \\
\hline $\begin{array}{c}\text { Абсолютна швидкість формування } \\
\text { фітомаси }\end{array}$ & $\mathrm{AGR}=\mathrm{W} / \mathrm{Ag}$ & г/рік \\
\hline $\begin{array}{c}\text { Абсолютна швидкість приросту } \\
\text { у висоту }\end{array}$ & $\mathrm{AGRH}=\mathrm{h} / \mathrm{Ag}$ & $\mathrm{cm} / \mathrm{pi \kappa}$ \\
\hline $\begin{array}{c}\text { Абсолютна швидкість приросту } \\
\text { за діаметром }\end{array}$ & $\mathrm{AGRD}=\mathrm{d} / \mathrm{Ag}$ & $\mathrm{cm} / \mathrm{pi \kappa}$ \\
\hline $\begin{array}{c}\text { Абсолютна швидкість формування } \\
\text { бічних пагонів першого порядку }\end{array}$ & $\mathrm{AGRB}=\mathrm{B}_{1} / \mathrm{Ag}$ & шт./piк \\
\hline
\end{tabular}

Таблиця 4

Класифікаційна схема фітоценозів лісової рослинності Лівобережного Полісся України, у яких проводилися дослідження

\begin{tabular}{|c|c|c|}
\hline \multicolumn{3}{|c|}{ ТИП РОСЛИННОСТІ - SILVAЕ } \\
\hline Формація & Субформація & Група асоціацій \\
\hline \multirow{13}{*}{$\begin{array}{l}\text { Pineta } \\
\text { sylvestris }\end{array}$} & \multirow{10}{*}{ Pineeta sylvestris } & 1. Pineta (sylvestris) hylocomiosa \\
\hline & & $\begin{array}{l}\text { 2. Pineta (sylvestris) calamagrostidosa } \\
\text { (epigeioris) }\end{array}$ \\
\hline & & 3. Pineta (sylvestris) nardosa (strictae) \\
\hline & & $\begin{array}{l}\text { 4. Pineta (sylvestris) coryloso } \\
\text { (avellanae) - vacciniosa (myrtilli) }\end{array}$ \\
\hline & & 5. Pineta (sylvestris) asarosa (europaei) \\
\hline & & 6. Pineta (sylvestris) pteridiosa (aquilini) \\
\hline & & $\begin{array}{l}\text { 7. Pineta (sylvestris) franguloso (alni) - } \\
\text { vacciniosa (myrtilli) }\end{array}$ \\
\hline & & 8. Pineta (sylvestris) vacciniosa (myrtilli) \\
\hline & & $\begin{array}{l}\text { 9. Pineta (sylvestris) moliniosa } \\
\text { (caeruleae) }\end{array}$ \\
\hline & & 10. Pineta (sylvestris) sphagnosa \\
\hline & \multirow{2}{*}{$\begin{array}{l}\text { Querceto (roboris) - } \\
\text { Pineta (sylvestris) }\end{array}$} & $\begin{array}{l}\text { 11. Querceto (roboris) - Pineta } \\
\text { (sylvestris) vacciniosa (myrtilli) }\end{array}$ \\
\hline & & $\begin{array}{l}\text { 12. Querceto (roboris) - Pineta } \\
\text { (sylvestris) corylosa (avellanae) sparsi } \\
\text { herbosa }\end{array}$ \\
\hline & $\begin{array}{l}\text { Betuleto (pendulae) - } \\
\text { Pineta (sylvestris) }\end{array}$ & $\begin{array}{l}\text { 13. Betuleto (pendulae) - Pineta } \\
\text { (sylvestris) vacciniosa (myrtilli) }\end{array}$ \\
\hline
\end{tabular}


Продовження таблиці 4

\begin{tabular}{|c|c|c|}
\hline \multicolumn{3}{|c|}{ ТИП РОСЛИННОСТІ - SILVAЕ } \\
\hline Формація & Субформація & Група асоціацій \\
\hline \multirow{7}{*}{$\begin{array}{l}\text { Querceta } \\
\text { roboris }\end{array}$} & \multirow{4}{*}{ Querceeta roboris } & $\begin{array}{l}\text { 14. Querceta (roboris) majanthemosa } \\
\text { (bifolii) }\end{array}$ \\
\hline & & $\begin{array}{l}\text { 15. Querceta (roboris) aegopodiosa } \\
\text { (podagrariae) }\end{array}$ \\
\hline & & $\begin{array}{l}\text { 16. Querceta (roboris) convallariosa } \\
\text { (majalis) }\end{array}$ \\
\hline & & $\begin{array}{l}\text { 17. Querceta (roboris) coryloso } \\
\text { (avellanae) - convallariosa (majalis) }\end{array}$ \\
\hline & \multirow{2}{*}{$\begin{array}{c}\text { Acereto } \\
\text { (platanoiditis) - } \\
\text { Querceta (roboris) }\end{array}$} & $\begin{array}{l}\text { 18. Acereto (platanoiditis) - Querceta } \\
\text { (roboris) coryloso (avellanae) - } \\
\text { aegopodiosa (podagrariae) }\end{array}$ \\
\hline & & $\begin{array}{l}\text { 19. Acereto (platanoiditis) - Querceta } \\
\text { (roboris) stellariosa (holosteae) }\end{array}$ \\
\hline & $\begin{array}{l}\text { Tilieto (cordatae) - } \\
\text { Querceta (roboris) }\end{array}$ & $\begin{array}{l}\text { 20. Tilieto (cordatae) - Querceta } \\
\text { (roboris) stellariosa (holosteae) }\end{array}$ \\
\hline \multirow{3}{*}{$\begin{array}{l}\text { Betuleta } \\
\text { pendulae }\end{array}$} & \multirow{3}{*}{ Betuleeta pendulae } & $\begin{array}{l}\text { 21. Betuleta (pendulae) vacciniosa } \\
\text { (myrtilli) }\end{array}$ \\
\hline & & $\begin{array}{l}\text { 22. Betuleta (pendulae) caricosa } \\
\text { (pilosae) }\end{array}$ \\
\hline & & $\begin{array}{l}\text { 23. Betuleta (pendulae) stellariosa } \\
\text { (holosteae) }\end{array}$ \\
\hline $\begin{array}{l}\text { Populeta } \\
\text { tremulae }\end{array}$ & Populeeta tremulae & $\begin{array}{l}\text { 24. Populeta (tremulae) stellariosa } \\
\text { (holosteae) }\end{array}$ \\
\hline
\end{tabular}

Проведено аналіз зміни розмірних ознак лісоутворювальних видів вздовж градієнтів екочинників. Найбільш детально досліджено градієнти вологості, родючості грунтів, зімкнутості лісу тощо. Для всіх видів градієнти досліджуваних чинників, відповідно, формували такі тренди: сухо $\rightarrow$ волого, бідні грунти $\rightarrow$ родючі грунти, низька зімкнутість деревостану $\rightarrow$ висока.

Під час дослідження реагування розмірних ознак дерев на прості екологічні градієнти спирались на класичні лісотипологічні підходи Г.Ф. Морозова, В.М. Сукачова, П.С. Погребняка ${ }^{14} 1516$, використання яких забезпечує досягнення оптимального співвідношення деталізації та генералізації даних. Принципова позиція під час дослідження

\footnotetext{
${ }_{15}^{14}$ Морозов Г.Ф. Учение о лесе Москва : Гослесбумиздат, 1949. $456 \mathrm{c}$.

15 Погребняк П.С. Основы лесной типологии. Киев : изд-во АН Украинской CCP, $1955.455 \mathrm{c}$.

${ }_{16}^{16}$ Сукачев В.Н., Зонн С.В. Методические указания к изучению типов леса. Москва : АН СССР, 1961. 143 с.
} 
градієнтів тих чи інших екологічних чинників полягала в тому, що лісові угруповання та їхні місцеіснування, представлені на кожному ступені, повинні чітко різнитися за параметрами чинника, що досліджується, а за іншими еколого-ценотичними характеристиками бути якомога більш подібними ${ }^{17}$.

\section{2. Результати досліджень та їх обговорення}

Розмірні величини, притаманні когортам провідних лісоутворювальних видів у різних лісових фітоценозах Лівобережного Полісся України, представлені в табл. 5-11 (на прикладі P. sylvestris). Встановлено, що когорти 3 різних угруповань, груп асоціацій $\mathrm{i}$, зрештою, формацій статистично достовірно різняться за морфометричними показниками. Відмінності у розмірних величинах проявляються вже на рівні сходів та проростків.

Формування розмірних показників у особин і когорт відбувається на тлі статистично достовірного впливу таких чинників, як вологість та родючість грунту, зімкнутість верхніх ярусів лісового фітоценозу, у дрібного підросту, проростків і сходів - проєктивного покриття трав'яно-чагарничкового ярусу, а у особин двох останніх когорт - ще й товщих підстилок (табл. 12). У сходів $Q$. robur зареєстрований тісний, статистично достовірний кореляційний взаємозв'язок $(\mathrm{r}=0,76)$ між масою жолудів та проростків.

Загалом у провідних лісоутворювальних видів у регіоні досліджень характер динаміки значень морфометричних показників за градієнтами зазначених чинників відповідає наявним науковим напрацюванням щодо вимогливості кожного виду до еколого-ценотичних умов місцезростань. У когорт лісоутворювальних видів має місце тенденція до збільшення величин статичних метричних показників під час зростання родючості грунту. Значення цієї групи розмірних величин, навпаки, зменшуються за збільшення проєктивного покриття нижніх ярусів лісу та зростання товщини підстилки.

17 Скляр В.Г. Природне поновлення провідних лісоутворювальних видів Новгород-Сіверського Полісся: реалізовані екологічні ніші та їхня динаміка. Украӥнський ботанічний журнал. 2014. Т. 71. № 1. С. 8-16. 
Таблиця 5

Величини провідних морфометричних параметрів когорт генеративних дерев Pinus sylvestris у різних групах асоціацій

\begin{tabular}{|c|c|c|c|c|}
\hline \multirow{2}{*}{ № } & \multirow{2}{*}{ Група асоціацій } & $\begin{array}{c}\text { Висота } \\
\text { особин, м }\end{array}$ & $\begin{array}{c}\text { Діаметр } \\
\text { стовбура, см }\end{array}$ & HDR, $\mathbf{m} / \mathbf{c m}$ \\
\hline & & $\overline{\mathrm{X}} \pm S_{\bar{x}}$ & $\overline{\mathrm{X}} \pm S_{\bar{x}}$ & $\overline{\mathrm{X}} \pm S_{\bar{x}}$ \\
\hline 1 & $\begin{array}{l}\text { Pineta (sylvestris) } \\
\text { hylocomiosa }\end{array}$ & $23,9 \pm 0,38$ & $26,8 \pm 0,64$ & $0,924 \pm 0,0143$ \\
\hline 2 & $\begin{array}{l}\text { Pineta (sylvestris) } \\
\text { calamagrostidosa } \\
\quad \text { (epigeioris) }\end{array}$ & $28,1 \pm 0,78$ & $33,2 \pm 1,76$ & $0,876 \pm 0,0424$ \\
\hline 3 & $\begin{array}{c}\text { Pineta (sylvestris) nardosa } \\
\text { (strictae) }\end{array}$ & $27,3 \pm 0,36$ & $35,8 \pm 1,45$ & $0,770 \pm 0,0346$ \\
\hline 4 & $\begin{array}{c}\text { Pineta (sylvestris) coryloso } \\
\text { (avellanae) - vacciniosa } \\
\text { (myrtilli) }\end{array}$ & $31,8 \pm 1,11$ & $35,4 \pm 3,50$ & $0,949 \pm 0,0902$ \\
\hline 5 & $\begin{array}{c}\text { Pineta (sylvestris) asarosa } \\
\text { (europaei) }\end{array}$ & $31,0 \pm 0,01$ & $32,8 \pm 1,94$ & $0,951 \pm 0,0558$ \\
\hline 7 & $\begin{array}{c}\text { Pineta (sylvestris) } \\
\text { franguloso (alni) - } \\
\text { vacciniosa (myrtilli) }\end{array}$ & $28,9 \pm 0,27$ & $32,0 \pm 1,03$ & $0,939 \pm 0,0395$ \\
\hline 8 & $\begin{array}{c}\text { Pineta (sylvestris) vacciniosa } \\
\text { (myrtilli) }\end{array}$ & $29,8 \pm 0,75$ & $32,3 \pm 3,54$ & $0,999 \pm 0,1043$ \\
\hline 9 & $\begin{array}{c}\text { Pineta (sylvestris) moliniosa } \\
\text { (caeruleae) }\end{array}$ & $31,0 \pm 0,58$ & $42,3 \pm 0,66$ & $0,734 \pm 0,0021$ \\
\hline 10 & Pineta (sylvestris) sphagnosa & $20,0 \pm 2,42$ & $26,1 \pm 3,38$ & $0,863 \pm 0,1378$ \\
\hline 11 & $\begin{array}{c}\text { Querceto (roboris) - Pineta } \\
\text { (sylvestris) vacciniosa } \\
\text { (myrtilli) }\end{array}$ & $33,7 \pm 0,72$ & $36,3 \pm 3,60$ & $1,096 \pm 0,2196$ \\
\hline 12 & $\begin{array}{c}\text { Querceto (roboris) - Pineta } \\
\text { (sylvestris) corylosa } \\
\text { (avellanae) sparsi herbosa }\end{array}$ & $25,5 \pm 1,19$ & $26,9 \pm 2,45$ & $0,966 \pm 0,0596$ \\
\hline 13 & $\begin{array}{c}\text { Betuleto (pendulae) - Pineta } \\
\text { (sylvestris) vacciniosa } \\
\text { (myrtilli) }\end{array}$ & $24,4 \pm 1,38$ & $24,2 \pm 1,70$ & $1,026 \pm 0,0333$ \\
\hline 20 & $\begin{array}{c}\text { Tilieto (cordatae) - Querceta } \\
\text { (roboris) stellariosa } \\
\text { (holosteae) }\end{array}$ & $27,0+0,29$ & $19,1+0,18$ & $1,419+0,0033$ \\
\hline 22 & $\begin{array}{c}\text { Betuleta (pendulae) caricosa } \\
\text { (pilosae) }\end{array}$ & $23,0 \pm 1,15$ & $33,8 \pm 3,49$ & $0,693 \pm 0,0375$ \\
\hline 24 & $\begin{array}{c}\text { Populeta (tremulae) } \\
\text { stellariosa (holosteae) }\end{array}$ & $33,0 \pm 0,58$ & $41,6 \pm 2,59$ & $0,798 \pm 0,0419$ \\
\hline & Загальне & $25,9 \pm 0,30$ & $29,2 \pm 0,51$ & $0,932 \pm 0,145$ \\
\hline & Довірчий рівень, $\mathrm{p}$ & 0,0000 & 0,0000 & 0,0011 \\
\hline
\end{tabular}

Примітки: тут і далі в табл. 6-11 для різних когорт нумерачія груп асоиіацій наведена відповідно до їх нумераиії у класифікаційній схемі (табл. 4);

тут і далі в табл. 6-12 для різних когорт довірчий рівень (р) розрахований за результатами дисперсійного аналізу 
Таблиця 6

Величини провідних морфометричних параметрів когорт молодих дерев Pinus sylvestris

\begin{tabular}{|c|c|c|c|c|}
\hline \multirow{2}{*}{ № } & Група асоціацій & $\begin{array}{c}\text { Висота } \\
\text { особин, м }\end{array}$ & $\begin{array}{c}\text { Діаметр } \\
\text { стовбура, см }\end{array}$ & HDR, м/см \\
\cline { 3 - 5 } & $\begin{array}{c}\overline{\mathrm{X}} \pm S_{\bar{x}} \\
\overline{\mathrm{X}} \pm S_{\bar{x}}\end{array}$ & $\overline{\mathrm{X}} \pm S_{\bar{x}}$ \\
\hline 1 & $\begin{array}{c}\text { Pineta (sylvestris) } \\
\text { hylocomiosa }\end{array}$ & $12,1 \pm 0,33$ & $11,8 \pm 0,54$ & $1,084 \pm 0,0292$ \\
\hline 6 & $\begin{array}{c}\text { Pineta (sylvestris) pteridiosa } \\
\text { (aquilini) }\end{array}$ & $17,1 \pm 0,36$ & $15,6 \pm 0,89$ & $1,164 \pm 0,0561$ \\
\hline 7 & $\begin{array}{c}\text { Pineta (sylvestris) franguloso } \\
\text { (alni) - vacciniosa (myrtilli) }\end{array}$ & $9,0 \pm 0,01$ & $10,2 \pm 0,02$ & $0,882 \pm 0,0010$ \\
\hline 8 & $\begin{array}{c}\text { Pineta (sylvestris) vacciniosa } \\
\text { (myrtilli) }\end{array}$ & $16,0 \pm 0,37$ & $16,7 \pm 0,92$ & $0,988 \pm 0,0384$ \\
\hline 10 & Pineta (sylvestris) sphagnosa & $8,8 \pm 0,12$ & $9,7 \pm 0,29$ & $0,909 \pm 0,0151$ \\
\hline 13 & $\begin{array}{c}\text { Betuleto (pendulae) }- \text { Pineta } \\
\text { (sylvestris) vacciniosa } \\
\text { (myrtilli) }\end{array}$ & $13,0 \pm 0,01$ & $12,0 \pm 0,01$ & $1,083 \pm 0,0009$ \\
\hline 22 & $\begin{array}{c}\text { Betuleta (pendulae) caricosa } \\
\text { (pilosae) }\end{array}$ & $18,1 \pm 1,15$ & $16,0 \pm 0,69$ & $1,141 \pm 0,1216$ \\
\hline & Загальне & $13,9 \pm 0,32$ & $13,5 \pm 0,42$ & $1,076 \pm 0,0213$ \\
\hline & Довірчий piвень (p) & 0,0000 & 0,0000 & 0,0498 \\
\hline
\end{tabular}

Таблиця 7

\section{Величини провідних морфометричних параметрів великого підросту Pinus sylvestris}

\begin{tabular}{|c|c|c|c|c|}
\hline \multirow{2}{*}{ № } & \multirow{2}{*}{ Група асоціацій } & $\begin{array}{c}\text { Висота } \\
\text { особин, м }\end{array}$ & $\begin{array}{c}\text { Діаметр } \\
\text { стовбура, см }\end{array}$ & HDR, $\mathrm{M} / \mathrm{cm}$ \\
\hline & & $\overline{\mathrm{X}} \pm S_{\bar{x}}$ & $\overline{\mathrm{X}} \pm S_{\bar{x}}$ & $\overline{\mathrm{X}} \pm S_{\bar{x}}$ \\
\hline 1 & $\begin{array}{l}\text { Pineta (sylvestris) } \\
\text { hylocomiosa }\end{array}$ & $4,6 \pm 0,49$ & $6,3 \pm 0,42$ & $0,731 \pm 0,0525$ \\
\hline 7 & $\begin{array}{c}\text { Pineta (sylvestris) franguloso } \\
\text { (alni) - vacciniosa (myrtilli) }\end{array}$ & $5,9 \pm 0,99$ & $7,8 \pm 0,81$ & $0,760 \pm 0,0085$ \\
\hline 10 & Pineta (sylvestris) sphagnosa & $7,4 \pm 0,23$ & $8,0 \pm 0,64$ & $0,955 \pm 0,0618$ \\
\hline 21 & $\begin{array}{l}\text { Betuleta (pendulae) } \\
\text { vacciniosa (myrtilli) }\end{array}$ & $7,0 \pm 0,01$ & $11,2 \pm 0,03$ & $0,625 \pm 0,0064$ \\
\hline & Загальне & $5,9 \pm 0,034$ & $7,5 \pm 0,41$ & $0,795 \pm 0,0377$ \\
\hline & Довірчий рівень, p & 0,000626 & 0,000532 & 0,015547 \\
\hline
\end{tabular}


Таблиця 8

Величини провідних морфометричних параметрів середнього підросту Pinus sylvestris у різних групах асоціацій

\begin{tabular}{|c|c|c|c|c|}
\hline \multirow{2}{*}{ № } & \multirow{2}{*}{ Група асоціацій } & $\begin{array}{c}\text { Висота } \\
\text { особин, м }\end{array}$ & $\begin{array}{c}\text { Діаметр } \\
\text { стовбура, см }\end{array}$ & HDR, м/см \\
\hline & & $\overline{\mathrm{X}} \pm S_{\bar{x}}$ & $\overline{\mathrm{X}} \pm S_{\bar{x}}$ & $\overline{\mathrm{X}} \pm S_{\bar{x}}$ \\
\hline 1 & $\begin{array}{l}\text { Pineta (sylvestris) } \\
\text { hylocomiosa }\end{array}$ & $1,4 \pm 0,05$ & $2,5 \pm 0,11$ & $0,583 \pm 0,0117$ \\
\hline 2 & $\begin{array}{l}\text { Pineta (sylvestris) } \\
\text { calamagrostidosa } \\
\text { (epigeioris) }\end{array}$ & $1,2 \pm 0,18$ & $2,0 \pm 0,47$ & $0,613 \pm 0,0542$ \\
\hline 3 & $\begin{array}{c}\text { Pineta (sylvestris) nardosa } \\
\text { (strictae) }\end{array}$ & $1,1 \pm 0,12$ & $1,7 \pm 0,10$ & $0,620 \pm 0,0494$ \\
\hline 7 & $\begin{array}{l}\text { Pineta (sylvestris) } \\
\text { franguloso (alni)- } \\
\text { vacciniosa (myrtilli) }\end{array}$ & $1,0 \pm 0,07$ & $1,5 \pm 0,16$ & $0,758 \pm 0,0246$ \\
\hline 8 & $\begin{array}{c}\text { Pineta (sylvestris) } \\
\text { vacciniosa (myrtilli) }\end{array}$ & $0,9 \pm 0,05$ & $1,3 \pm 0,09$ & $0,726 \pm 0,0367$ \\
\hline 10 & $\begin{array}{l}\text { Pineta (sylvestris) } \\
\text { sphagnosa }\end{array}$ & $1,0 \pm 0,11$ & $1,4 \pm 0,22$ & $0,786 \pm 0,0334$ \\
\hline 11 & $\begin{array}{c}\text { Querceto (roboris) - Pineta } \\
\text { (sylvestris) vacciniosa } \\
\text { (myrtilli) }\end{array}$ & $0,9 \pm 0,12$ & $1,6 \pm 0,05$ & $0,574 \pm 0,0623$ \\
\hline 21 & $\begin{array}{l}\text { Betuleta (pendulae) } \\
\text { vacciniosa (myrtilli) }\end{array}$ & $0,8 \pm 0,05$ & $1,2 \pm 0,07$ & $0,673 \pm 0,0392$ \\
\hline 23 & $\begin{array}{c}\text { Betuleta (pendulae) } \\
\text { stellariosa (holosteae) }\end{array}$ & $0,8 \pm 0,01$ & $1,0 \pm 0,01$ & $0,798 \pm 0,0144$ \\
\hline & Загальне & $1,2 \pm 0,04$ & $2,1 \pm 0,08$ & $0,646 \pm 0,0104$ \\
\hline & Довірчий рівень (p) & 0,000031 & 0,000000 & $0,0 \overline{0} 0000$ \\
\hline
\end{tabular}

Таблиця 9

Величини провідних морфометричних параметрів у дрібного підросту Pinus sylvestris у різних групах асоціацій

\begin{tabular}{|c|c|c|c|c|c|c|}
\hline \multirow{2}{*}{ № } & \multirow{2}{*}{ Група асоціацій } & h, см & $\begin{array}{l}\text { Nmut, } \\
\text { IIIT. }\end{array}$ & d, $\mathbf{c m}$ & В & $\begin{array}{c}\text { Ag, } \\
\text { років }\end{array}$ \\
\hline & & $\overline{\mathrm{X}} \pm S_{\bar{x}}$ & $\overline{\mathrm{X}} \pm S_{\bar{x}}$ & $\overline{\mathrm{X}} \pm S_{\bar{x}}$ & $\overline{\mathrm{X}} \pm S_{\bar{x}}$ & $\overline{\mathrm{X}} \pm S_{\bar{x}}$ \\
\hline 1 & 2 & 3 & 4 & 5 & 6 & 7 \\
\hline 1 & $\begin{array}{c}\text { Pineta (sylvestris) } \\
\text { hylocomiosa }\end{array}$ & $\begin{array}{c}37,3 \pm \\
0,87\end{array}$ & $\begin{array}{l}4,4+ \\
0,13 \\
\end{array}$ & $0,50 \pm$ & $\begin{array}{l}7,6 \pm \\
0,29\end{array}$ & $\begin{array}{l}6,7 \pm \\
0,1 \pm \\
\end{array}$ \\
\hline 2 & $\begin{array}{l}\text { Pineta (sylvestris) } \\
\text { calamagrostidosa } \\
\text { (epigeioris) }\end{array}$ & $\begin{array}{c}40,7 \pm \\
2,84\end{array}$ & $\begin{array}{l}4,1 \pm \\
0,45\end{array}$ & $\begin{array}{l}0,50 \pm \\
0,05 \overline{7}\end{array}$ & $\begin{array}{l}6,8 \pm \\
0,6 \frac{1}{6}\end{array}$ & $6,9 \pm$ \\
\hline 3 & $\begin{array}{l}\text { Pineta (sylvestris) } \\
\text { nardosa (strictae) }\end{array}$ & $\begin{array}{c}36,5 \pm \\
4,00\end{array}$ & $\begin{array}{c}5,8 \pm \\
0,91\end{array}$ & $\begin{array}{l}0,57 \pm \\
0,047\end{array}$ & $\begin{array}{c}12,2 \pm \\
1,92\end{array}$ & $\begin{array}{l}8,0 \pm \\
0,8 \frac{6}{6}\end{array}$ \\
\hline 7 & $\begin{array}{l}\text { Pineta (sylvestris) } \\
\text { franguloso (alni) - } \\
\text { vacciniosa (myrtilli) }\end{array}$ & $\begin{array}{c}37,4 \pm \\
1,35\end{array}$ & $\begin{array}{l}4,3 \pm \\
0,30\end{array}$ & $\begin{array}{l}0,49 \pm \\
0,025\end{array}$ & $6,2 \pm$ & $\begin{array}{l}7,5 \pm \\
0,30\end{array}$ \\
\hline 8 & $\begin{array}{c}\text { Pineta (sylvestris) } \\
\text { vacciniosa (myrtilli) }\end{array}$ & $\begin{array}{c}39,9 \pm \\
2,81\end{array}$ & $\begin{array}{l}4,4 \pm \\
0,52\end{array}$ & $\begin{array}{l}0,51 \pm \\
0,051\end{array}$ & $\begin{array}{l}6,7 \pm \\
1,07\end{array}$ & $\begin{array}{l}7,8 \pm \\
0,42\end{array}$ \\
\hline 10 & $\begin{array}{c}\text { Pineta (sylvestris) } \\
\text { sphagnosa }\end{array}$ & $\begin{array}{c}38,3 \pm \\
1,67\end{array}$ & $\begin{array}{l}3,3 \pm \\
0,29 \\
\end{array}$ & $\begin{array}{r}0,42+ \\
0,02 \frac{4}{4}\end{array}$ & $\begin{array}{l}5,1 \pm \\
0,47\end{array}$ & $\begin{array}{l}7,3+ \\
0,28\end{array}$ \\
\hline 11 & $\begin{array}{c}\text { Querceto (roboris) - } \\
\text { Pineta (sylvestris) } \\
\text { vacciniosa (myrtilli) }\end{array}$ & $\begin{array}{c}38,7 \pm \\
2,45\end{array}$ & $\begin{array}{l}5,3 \pm \\
0,4 \overline{3}\end{array}$ & $0,56 \pm$ & $\begin{array}{l}7,6 \pm \\
0,7 \frac{7}{4}\end{array}$ & $\begin{array}{l}7,6 \pm \\
0,5 \overline{7}\end{array}$ \\
\hline
\end{tabular}


Продовження таблиці 9

\begin{tabular}{|c|c|c|c|c|c|c|}
\hline 1 & 2 & 3 & 4 & 5 & 6 & 7 \\
\hline 16 & $\begin{array}{c}\text { Querceta (roboris) } \\
\text { convallariosa (majalis) }\end{array}$ & $\begin{array}{c}42,6 \pm \\
2,39\end{array}$ & $\begin{array}{l}4,4+ \\
0,27\end{array}$ & $\begin{array}{l}0,53 \pm \\
0,031\end{array}$ & $\begin{array}{l}7,4 \pm \\
0,55\end{array}$ & $\begin{array}{l}6,6 \pm \\
0,27\end{array}$ \\
\hline 21 & $\begin{array}{l}\text { Betuleta (pendulae) } \\
\text { vacciniosa (myrtilli) }\end{array}$ & $\begin{array}{c}43,6 \pm \\
1,64\end{array}$ & $5,4 \pm$ & $0,61 \pm$ & $\begin{array}{l}8,7 \pm \\
0,78\end{array}$ & $\begin{array}{l}8,2 \pm \\
0,21\end{array}$ \\
\hline 23 & $\begin{array}{c}\text { Betuleta (pendulae) } \\
\text { stellariosa (holosteae) }\end{array}$ & $\begin{array}{c}46,5 \pm \\
2,20\end{array}$ & $\begin{array}{l}4,7 \pm \\
0,61\end{array}$ & $\begin{array}{l}0,49 \pm \\
0,035\end{array}$ & $\begin{array}{l}6,6 \pm \\
1,17\end{array}$ & $\begin{array}{l}7,7 \pm \\
0,36\end{array}$ \\
\hline & Загальне & $\begin{array}{c}38,7 \pm \\
0,57\end{array}$ & $\begin{array}{l}4,4 \pm \\
0,10\end{array}$ & $\begin{array}{c}0,51 \pm \\
0,00 \overline{9}\end{array}$ & $\begin{array}{l}7,3 \pm \\
0,20\end{array}$ & $\begin{array}{l}7,1 \pm \\
0,10\end{array}$ \\
\hline & Довірчий рівень (p) & 0,0332 & 0,0001 & 0,0011 & 0,0000 & 0,0007 \\
\hline \multirow{2}{*}{ № } & \multirow{2}{*}{ Група асоціацій } & Oxv, штT. & $\mathbf{W}, \mathbf{\Gamma}$ & $\begin{array}{l}\text { HDR, } \\
\text { cM/cM }\end{array}$ & $\begin{array}{c}\text { HWR, } \\
\text { cM/r }\end{array}$ & $\begin{array}{l}\text { B/h, } \\
\text { WT./cM }\end{array}$ \\
\hline & & $\overline{\mathrm{X}} \pm S_{\bar{x}}$ & $\overline{\mathrm{X}} \pm S_{\bar{x}}$ & $\overline{\mathrm{X}} \pm S_{\bar{x}}$ & $\overline{\overline{\mathrm{X}}} \pm S_{\bar{x}}$ & $\overline{\mathrm{X}} \pm S_{\bar{x}}$ \\
\hline 1 & $\begin{array}{l}\text { Pineta (sylvestris) } \\
\text { hylocomiosa }\end{array}$ & $\begin{array}{c}35,3 \pm \\
0,70\end{array}$ & $\begin{array}{c}14,9 \pm \\
0,82\end{array}$ & $\begin{array}{c}77,8 \pm \\
1,66\end{array}$ & $\begin{array}{l}3,8 \pm \\
0,20\end{array}$ & $\begin{array}{c}0,21 \pm \\
0,007\end{array}$ \\
\hline 2 & $\begin{array}{l}\text { Pineta (sylvestris) } \\
\text { calamagrostidosa } \\
\text { (epigeioris) }\end{array}$ & $\begin{array}{c}31,3 \pm \\
2,83\end{array}$ & $\begin{array}{c}14,3 \pm \\
2,78\end{array}$ & $\begin{array}{l}86,1 \pm \\
5,70\end{array}$ & $\begin{array}{l}3,5 \pm \\
0,45\end{array}$ & $\begin{array}{c}0,17 \pm \\
0,013\end{array}$ \\
\hline 3 & $\begin{array}{l}\text { Pineta (sylvestris) } \\
\text { nardosa (strictae) }\end{array}$ & $\begin{array}{l}45,5 \pm \\
3,08\end{array}$ & $\begin{array}{c}17,4 \pm \\
3,61\end{array}$ & $\begin{array}{l}68,3 \pm \\
10,31\end{array}$ & $\begin{array}{l}2,7 \pm \\
0,60\end{array}$ & $\begin{array}{c}0,37 \pm \\
0,099\end{array}$ \\
\hline 7 & $\begin{array}{l}\text { Pineta (sylvestris) } \\
\text { franguloso (alni)- } \\
\text { vacciniosa (myrtilli) }\end{array}$ & $29,0 \pm$ & $\begin{array}{r}13,2 \pm \\
1,20\end{array}$ & $\begin{array}{c}80,0 \pm \\
2,43\end{array}$ & $\begin{array}{r}4,0 \pm \\
0,40\end{array}$ & $0,16 \pm$ \\
\hline 8 & $\begin{array}{c}\text { Pineta (sylvestris) } \\
\text { vacciniosa (myrtilli) }\end{array}$ & $\begin{array}{c}19,6 \pm \\
0,96\end{array}$ & $\begin{array}{c}14,8 \pm \\
3,28\end{array}$ & $\begin{array}{c}84,5 \pm \\
7,91\end{array}$ & $3,6 \pm \frac{1}{2}$ & $\begin{array}{c}0,17 \pm \\
0,02 \frac{3}{3}\end{array}$ \\
\hline 10 & $\begin{array}{c}\text { Pineta (sylvestris) } \\
\text { sphagnosa }\end{array}$ & $\begin{array}{c}37,9 \pm \\
1,63\end{array}$ & $\begin{array}{l}9,2 \pm \\
0,99\end{array}$ & $\begin{array}{c}102,3 \pm \\
6,38\end{array}$ & $\begin{array}{l}5,6 \pm \\
0,50\end{array}$ & $\begin{array}{l}0,14 \pm \\
0,014\end{array}$ \\
\hline 11 & $\begin{array}{c}\text { Querceto - Pineta } \\
\text { (sylvestris) vacciniosa } \\
\text { (myrtilli) }\end{array}$ & $\begin{array}{l}37,2 \pm \\
2,59\end{array}$ & $\begin{array}{c}16,2 \pm \\
2,10\end{array}$ & $\begin{array}{c}73,5 \pm \\
3,97\end{array}$ & $\begin{array}{l}3,0 \pm \\
0,32\end{array}$ & $0,20 \pm$ \\
\hline 16 & $\begin{array}{c}\text { Querceta (roboris) } \\
\text { convallariosa (majalis) }\end{array}$ & $\begin{array}{c}37,1 \pm \\
1,91 \\
\end{array}$ & $\begin{array}{c}16,3 \pm \\
1,87 \\
\end{array}$ & $\begin{array}{c}80,9 \pm \\
1,64 \\
\end{array}$ & $\begin{array}{l}3,2 \pm \\
0,30\end{array}$ & $\begin{array}{c}0,17 \pm \\
0,01 \pm \\
\end{array}$ \\
\hline 21 & $\begin{array}{l}\text { Betuleta (pendulae) } \\
\text { vacciniosa (myrtilli) }\end{array}$ & $\begin{array}{c}40,9 \pm \\
2,48\end{array}$ & $\begin{array}{c}14,6 \pm \\
1,75 \\
\end{array}$ & $\begin{array}{c}73,1 \pm \\
3,79 \\
\end{array}$ & $\begin{array}{l}3,4 \pm \\
0,31\end{array}$ & $\begin{array}{c}0,20 \pm \\
0,015\end{array}$ \\
\hline \multirow[t]{3}{*}{23} & $\begin{array}{c}\text { Betuleta (pendulae) } \\
\text { stellariosa (holosteae) }\end{array}$ & $\begin{array}{c}32,7 \pm \\
3,60 \\
\end{array}$ & $\begin{array}{c}16,3 \pm \\
2,50\end{array}$ & $\begin{array}{c}97,3 \pm \\
9,40 \\
\end{array}$ & $\begin{array}{l}3,2 \pm \\
0,49\end{array}$ & $\begin{array}{l}0,14 \pm \\
0,024 \\
\end{array}$ \\
\hline & Загальне & $\begin{array}{c}34,9 \pm \\
0,54\end{array}$ & $\begin{array}{c}14,6 \pm \\
0,52\end{array}$ & $\begin{array}{c}81,0 \pm \\
1,29 \\
\end{array}$ & $\begin{array}{l}3,8 \pm \\
0,14 \\
\end{array}$ & $\begin{array}{l}0,19 \pm \\
0,005\end{array}$ \\
\hline & Довірчий рівень (р) & 0,0000 & 0,0003 & 0,0000 & 0,0011 & 0,0000 \\
\hline \multirow[t]{2}{*}{ № } & \multirow[t]{2}{*}{ Група асоціацій } & $\begin{array}{l}\text { AGRW, } \\
\text { г/piк }\end{array}$ & $\begin{array}{l}\text { AGRH, } \\
\text { см/piк }\end{array}$ & $\begin{array}{l}\text { AGRD, } \\
\text { см/рік }\end{array}$ & $\begin{array}{l}\text { AGRB, } \\
\text { шт./piк }\end{array}$ & $\begin{array}{l}\text { B_mut, } \\
\text { IITT. }\end{array}$ \\
\hline & & $\overline{\mathrm{X}} \pm S_{\bar{x}}$ & $\overline{\overline{\mathrm{X}} \pm S_{\bar{x}}}$ & $\overline{\mathrm{X}} \pm S_{\bar{x}}$ & $\overline{\overline{\mathrm{X}} \pm S_{\bar{x}}}$ & $\overline{\mathrm{X}} \pm S_{\bar{x}}$ \\
\hline 1 & $\begin{array}{c}\text { Pineta (sylvestris) } \\
\text { hylocomiosa }\end{array}$ & $\begin{array}{l}2,15 \pm \\
0,103\end{array}$ & $\begin{array}{l}5,7 \pm \\
0,12\end{array}$ & $0,08 \pm$ & $\begin{array}{l}1,14 \pm \\
0,039\end{array}$ & $\begin{array}{l}1,7 \pm \\
0,04\end{array}$ \\
\hline 2 & $\begin{array}{l}\text { Pineta (sylvestris) } \\
\text { calamagrostidosa } \\
\text { (epigeioris) }\end{array}$ & $\begin{array}{l}1,97 \pm \\
0,277\end{array}$ & $\begin{array}{l}6,0 \pm \\
0,42\end{array}$ & $0,07 \pm$ & $\begin{array}{l}1,01 \pm \\
0,110\end{array}$ & $\begin{array}{l}1,7 \pm \\
0,13\end{array}$ \\
\hline 3 & $\begin{array}{l}\text { Pineta (sylvestris) } \\
\text { nardosa (strictae) }\end{array}$ & $\begin{array}{l}2,21 \pm \\
0,470\end{array}$ & $\begin{array}{l}4,8+ \\
0,78\end{array}$ & $0,07 \pm$ & $\begin{array}{l}1,49+\frac{t}{5} \\
0,115\end{array}$ & $2,1 \pm$ \\
\hline 7 & $\begin{array}{l}\text { Pineta (sylvestris) } \\
\text { franguloso (alni)- } \\
\text { vacciniosa (myrtilli) }\end{array}$ & $\begin{array}{l}1,67 \pm \\
0,12 \overline{3}\end{array}$ & $\begin{array}{l}5,1 \pm \\
0,1 \overline{3}\end{array}$ & $0,07 \pm$ & $0,80+$ & $\begin{array}{l}1,4+ \\
0,05\end{array}$ \\
\hline 8 & $\begin{array}{c}\text { Pineta (sylvestris) } \\
\text { vacciniosa (myrtilli) }\end{array}$ & $\begin{array}{l}1,81 \pm \\
0,34 \overline{2}\end{array}$ & $\begin{array}{l}5,1 \pm \\
0,28\end{array}$ & $\begin{array}{l}0,06 \pm \\
0,005\end{array}$ & $\begin{array}{c}0,85 \pm \\
0,115\end{array}$ & $\begin{array}{l}1,5 \pm \\
0,13\end{array}$ \\
\hline
\end{tabular}


Закінчення таблиці 9

\begin{tabular}{|c|c|c|c|c|c|c|}
\hline 1 & 2 & 3 & 4 & 5 & 6 & 7 \\
\hline 10 & $\begin{array}{c}\text { Pineta (sylvestris) } \\
\text { sphagnosa }\end{array}$ & $\begin{array}{l}1,21 \pm \\
0,104\end{array}$ & $\begin{array}{l}5,3 \pm \\
0,19 \\
\end{array}$ & $\begin{array}{l}0,06 \pm \\
0,00 \frac{3}{3}\end{array}$ & $\begin{array}{l}0,68 \pm \\
0,050 \\
\end{array}$ & $\begin{array}{l}1,5 \pm \\
0,09\end{array}$ \\
\hline 11 & $\begin{array}{l}\text { Querceto (roboris) - } \\
\text { Pineta (sylvestris) } \\
\text { vacciniosa (myrtilli) }\end{array}$ & $\begin{array}{l}2,14+ \\
0,22 \frac{1}{3}\end{array}$ & $\begin{array}{l}5,5+ \\
0,36\end{array}$ & $\begin{array}{l}0,08+ \\
0,004\end{array}$ & $\begin{array}{l}0,99 \pm \\
0,065\end{array}$ & $1,4+$ \\
\hline 16 & $\begin{array}{c}\text { Querceta (roboris) } \\
\text { convallariosa (majalis) }\end{array}$ & $\begin{array}{l}2,42 \pm \\
0,251\end{array}$ & $\begin{array}{l}6,5 \pm \\
0,3 \frac{1}{2}\end{array}$ & $\begin{array}{l}0,08 \pm \\
0,004\end{array}$ & $\begin{array}{l}1,12 \pm \\
0,075\end{array}$ & $\begin{array}{l}1,7 \pm \\
0,11\end{array}$ \\
\hline 21 & $\begin{array}{l}\text { Betuleta (pendulae) } \\
\text { vacciniosa (myrtilli) }\end{array}$ & $\begin{array}{l}1,81 \pm \\
0,211\end{array}$ & $\begin{array}{l}5,3 \pm \\
0,20\end{array}$ & $\begin{array}{l}0,07 \pm \\
0,00 \overline{3}\end{array}$ & $\begin{array}{l}1,06 \pm \\
0,091\end{array}$ & $\begin{array}{l}1,6 \pm \\
0,1 \frac{1}{2}\end{array}$ \\
\hline 23 & $\begin{array}{c}\text { Betuleta (pendulae) } \\
\text { stellariosa (holosteae) }\end{array}$ & $\begin{array}{r}2,23 \pm \\
0,440 \\
\end{array}$ & $\begin{array}{l}6,1 \pm+ \\
0,43 \\
\end{array}$ & $\begin{array}{l}0,07 \pm \\
0,005\end{array}$ & $\begin{array}{l}0,86+ \\
0,14 \overline{6}\end{array}$ & $\begin{array}{l}1,3 \pm \\
0,0,9 \\
\end{array}$ \\
\hline & Загальне & $\begin{array}{l}1,98+ \\
0,06 \overline{4}\end{array}$ & $\begin{array}{l}5,6+ \\
0,0 \overline{8}\end{array}$ & $\begin{array}{r}0,7 \pm \\
0,01\end{array}$ & $\begin{array}{l}1,02 \pm \\
0,25\end{array}$ & $\begin{array}{l}1,6 \pm \\
0,0 \frac{3}{3}\end{array}$ \\
\hline & Довірчий рівень (р) & 0,0001 & 0,0241 & 0,0000 & 0,0000 & 0,0001 \\
\hline
\end{tabular}

Примітка: тут і далі в табл. 10-12 умовні позначення морфопараметрів наведені відповідно до табл. 1-3

Таблиця 10

Величини провідних морфометричних параметрів у сходів Pinus sylvestris

\begin{tabular}{|c|c|c|c|c|c|c|}
\hline \multirow[t]{2}{*}{ № } & \multirow[t]{2}{*}{ Асоціації } & h, см & L_kr, cm & $\mathbf{W}, \mathbf{\Gamma}$ & $\underset{\mathrm{cm} / \Gamma}{\mathbf{H W R}}$ & $\mathbf{h} / \mathbf{L} \_\mathbf{k r}$ \\
\hline & & $\overline{\mathrm{X}} \pm S_{\bar{x}}$ & $\overline{\mathrm{X}} \pm S_{\bar{x}}$ & $\overline{\mathrm{X}} \pm S_{\bar{x}}$ & $\overline{\mathrm{X}} \pm S_{\bar{x}}$ & $\overline{\mathrm{X}} \pm S_{\bar{x}}$ \\
\hline 1 & $\begin{array}{l}\text { Pinetum (sylvestris) } \\
\text { sparsi herbosum }\end{array}$ & $\begin{array}{l}2,7 \pm \\
0,11 \\
\end{array}$ & $\begin{array}{l}4,6 \pm \\
0,22\end{array}$ & $\begin{array}{l}0,10 \pm \\
0,01 \overline{3}\end{array}$ & $\begin{array}{l}55,6 \pm \\
14,59\end{array}$ & $\begin{array}{l}0,63 \pm \\
0,04 \frac{2}{2}\end{array}$ \\
\hline 2 & $\begin{array}{c}\text { Pinetum (sylvestris) } \\
\text { hylocomiosum }\end{array}$ & $\begin{array}{l}3,3 \pm \\
0,05 \\
\end{array}$ & $\begin{array}{l}3,6 \pm \\
0,10 \\
\end{array}$ & $0,08 \pm$ & $\begin{array}{c}50,1 \pm \\
1,91\end{array}$ & $0,99 \pm$ \\
\hline 3 & $\begin{array}{l}\text { Querceto (roboris) - } \\
\text { Pinetum (sylvestris) } \\
\text { vacciniosum } \\
\text { (myrtilli) }\end{array}$ & $\begin{array}{l}3,1 \pm \\
0,10\end{array}$ & $\begin{array}{l}2,4 \pm \\
0,15\end{array}$ & $0,06 \pm$ & $\begin{array}{c}59,2 \pm \\
5,46\end{array}$ & $\begin{array}{l}1,37 \pm \\
0,134\end{array}$ \\
\hline & Загальне & $\begin{array}{l}3,1+\frac{ \pm}{5} \\
0,05\end{array}$ & $\begin{array}{l}3,5 \pm \\
0,09\end{array}$ & $\begin{array}{c}0,08+\frac{+}{3} \\
0,000\end{array}$ & $\begin{array}{c}52,5 \pm \\
2,65\end{array}$ & $\begin{array}{l}1,03+ \\
0,038\end{array}$ \\
\hline & Довірчий рівень (р) & 0,000130 & 0,000000 & 0,009311 & 0,387480 & 0,000000 \\
\hline
\end{tabular}

Таблиця 11

Величини провідних морфометричних параметрів у проростків Pinus sylvestris у різних асоціаціях лісової рослинності

\begin{tabular}{|c|c|c|c|c|c|c|}
\hline \multirow{2}{*}{ № } & \multirow{2}{*}{ Асоціації } & $\mathbf{h}, \mathbf{c m}$ & $\begin{array}{l}\text { Nmut, } \\
\text { UIT. }\end{array}$ & d, см & $\begin{array}{c}\text { Oxv_5, } \\
\text { UIT. }\end{array}$ & $\mathbf{W}, \mathbf{\Gamma}$ \\
\hline & & $\overline{\mathrm{X}} \pm S_{\bar{x}}$ & $\overline{\mathrm{X}} \pm S_{\bar{x}}$ & $\overline{\mathrm{X}} \pm S_{\bar{x}}$ & $\overline{\mathrm{X}} \pm S_{\bar{x}}$ & $\overline{\mathrm{X}} \pm S_{\bar{x}}$ \\
\hline 1 & $\begin{array}{l}\text { Pinetum (sylvestris) } \\
\text { sparsi herbosum }\end{array}$ & $8,7 \pm 0,68$ & $\begin{array}{l}0,11 \pm \\
0,011\end{array}$ & $\begin{array}{l}0,14 \pm \\
0,009\end{array}$ & $\begin{array}{c}39,4 \pm \\
2,21\end{array}$ & $\begin{array}{l}1,1 \pm \\
0,20\end{array}$ \\
\hline 2 & $\begin{array}{l}\text { Pinetum (sylvestris) } \\
\text { hylocomiosum }\end{array}$ & $9,9 \pm 0,58$ & $0,28 \pm$ & $\begin{array}{l}0,14 \pm \\
0,010\end{array}$ & $\begin{array}{l}40,2 \pm \\
4,04\end{array}$ & $\begin{array}{l}1,6 \pm \\
0,27\end{array}$ \\
\hline 3 & $\begin{array}{l}\text { Querceto (roboris) - } \\
\text { Pinetum (sylvestris) } \\
\text { vacciniosum } \\
\text { (myrtilli) }\end{array}$ & $17,6 \pm 1,05$ & $\begin{array}{l}1,53 \pm \\
0,13 \overline{3}\end{array}$ & $0,21 \pm$ & $\begin{array}{c}25,5 \pm \\
1,50\end{array}$ & $\begin{array}{l}3,1 \pm \\
0,51\end{array}$ \\
\hline & Загальне & $11,1 \pm 0,56$ & $\begin{array}{c}0,49 \pm \frac{ \pm}{9} \\
0,089\end{array}$ & $\begin{array}{l}0,16 \pm \\
0,009\end{array}$ & $\begin{array}{c}30,6 \pm \\
2,41\end{array}$ & $\begin{array}{l}1,8 \pm \\
0,20\end{array}$ \\
\hline & Довірчий рівень (р) & 0,000000 & 0,000000 & 0,000515 & 0,000002 & 0,002019 \\
\hline
\end{tabular}


Продовження таблиці 11

\begin{tabular}{|c|c|c|c|c|c|c|}
\hline \multirow{2}{*}{ № } & \multirow{2}{*}{ Асоціації } & $\begin{array}{l}\text { HDR, } \\
\text { cM/cM }\end{array}$ & $\begin{array}{l}\text { HWR, } \\
\text { cM/r }\end{array}$ & $\begin{array}{c}\text { AGRW, } \\
\text { г/рік }\end{array}$ & $\begin{array}{c}\text { AGRH, } \\
\text { см/piк }\end{array}$ & $\begin{array}{c}\text { AGRD, } \\
\text { см/рiк }\end{array}$ \\
\hline & & $\overline{\mathrm{X}} \pm S_{\bar{x}}$ & $\overline{\mathrm{X}} \pm S_{\bar{x}}$ & $\overline{\mathrm{X}} \pm S_{\bar{x}}$ & $\overline{\mathrm{X}} \pm S_{\bar{x}}$ & $\overline{\mathrm{X}} \pm S_{\bar{x}}$ \\
\hline 1 & $\begin{array}{l}\text { Pinetum (sylvestris) } \\
\text { sparsi herbosum }\end{array}$ & $60,3 \pm 2,47$ & $\begin{array}{c}12,9 \pm \\
2,82\end{array}$ & $\begin{array}{c}0,51 \pm \\
0,07 \overline{9}\end{array}$ & $\begin{array}{l}4,1 \pm \\
0,25\end{array}$ & $\begin{array}{l}0,07 \pm \\
0,004\end{array}$ \\
\hline 2 & $\begin{array}{c}\text { Pinetum (sylvestris) } \\
\text { hylocomiosum }\end{array}$ & $77,8 \pm 3,55$ & $\begin{array}{c}12,7 \pm \\
1,36 \\
\end{array}$ & $\begin{array}{l}0,67 \pm \\
0,098 \\
\end{array}$ & $\begin{array}{l}4,6 \pm \\
0,19 \\
\end{array}$ & $\begin{array}{l}0,06 \pm \\
0,004\end{array}$ \\
\hline 3 & $\begin{array}{l}\text { Querceto (roboris) - } \\
\text { Pinetum (sylvestris) } \\
\text { vacciniosum } \\
\text { (myrtilli) }\end{array}$ & $85,0 \pm 3,76$ & $\begin{array}{l}7,5 \pm \\
0,94\end{array}$ & $\begin{array}{l}1,10 \pm+ \\
0,168\end{array}$ & $\begin{array}{l}6,3 \pm \\
0,42\end{array}$ & $0,08+\frac{+}{0,005}$ \\
\hline & Загальне & $75,0 \pm 2,41$ & $\begin{array}{c}11,7 \pm \\
1,05\end{array}$ & $\begin{array}{l}0,72 \pm \\
0,070\end{array}$ & $\begin{array}{l}4,8+ \\
0,17 \\
\end{array}$ & $\begin{array}{c}0,07 \pm \\
0,03\end{array}$ \\
\hline & Довірчий рівень (p) & 0,001103 & 0,136882 & 0,016415 & 0,000006 & 0,248891 \\
\hline
\end{tabular}

У когорт усіх видів найбільші за розміром рослини формувалися у фітоценозах із зімкнутістю 0,4-0,6. Найбільшими за розміром були особини 3 територій, які, відповідно до класифікації, П.С. Погребняка ${ }^{18}$,репрезентували свіжі, або рідше вологі гігротопи. Несприятливими виступали як сухі, так і перезволожені місцезростання. Характер зміни у когорт величин основних морфометричних показників на градієнтах провідних екологічних чинників проілюстрований на рис. 1-6.

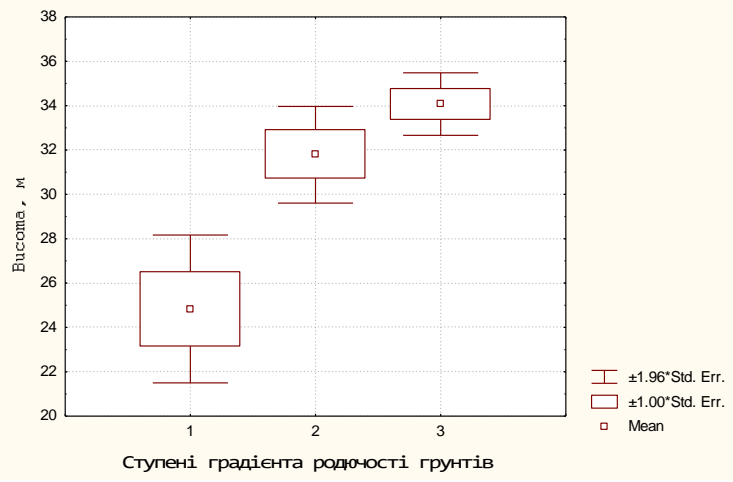

Рис. 1. Зміна висоти генеративних дерев Pinus sylvestris за градіснтом родючості грунту; групи асоціацій, що відповідають ступеням градіснта: 1) Pineta (sylvestris) hylocomiosa; 2) Pineta (sylvestris) coryloso (avellanae) vacciniosa (myrtilli); 3) Querceto (roboris) -

Pineta (sylvestris) vacciniosa (myrtilli)

18 Погребняк П.С. Основы лесной типологии. Киев : изд-во АН Украинской CCP, 1955. $455 \mathrm{c}$. 


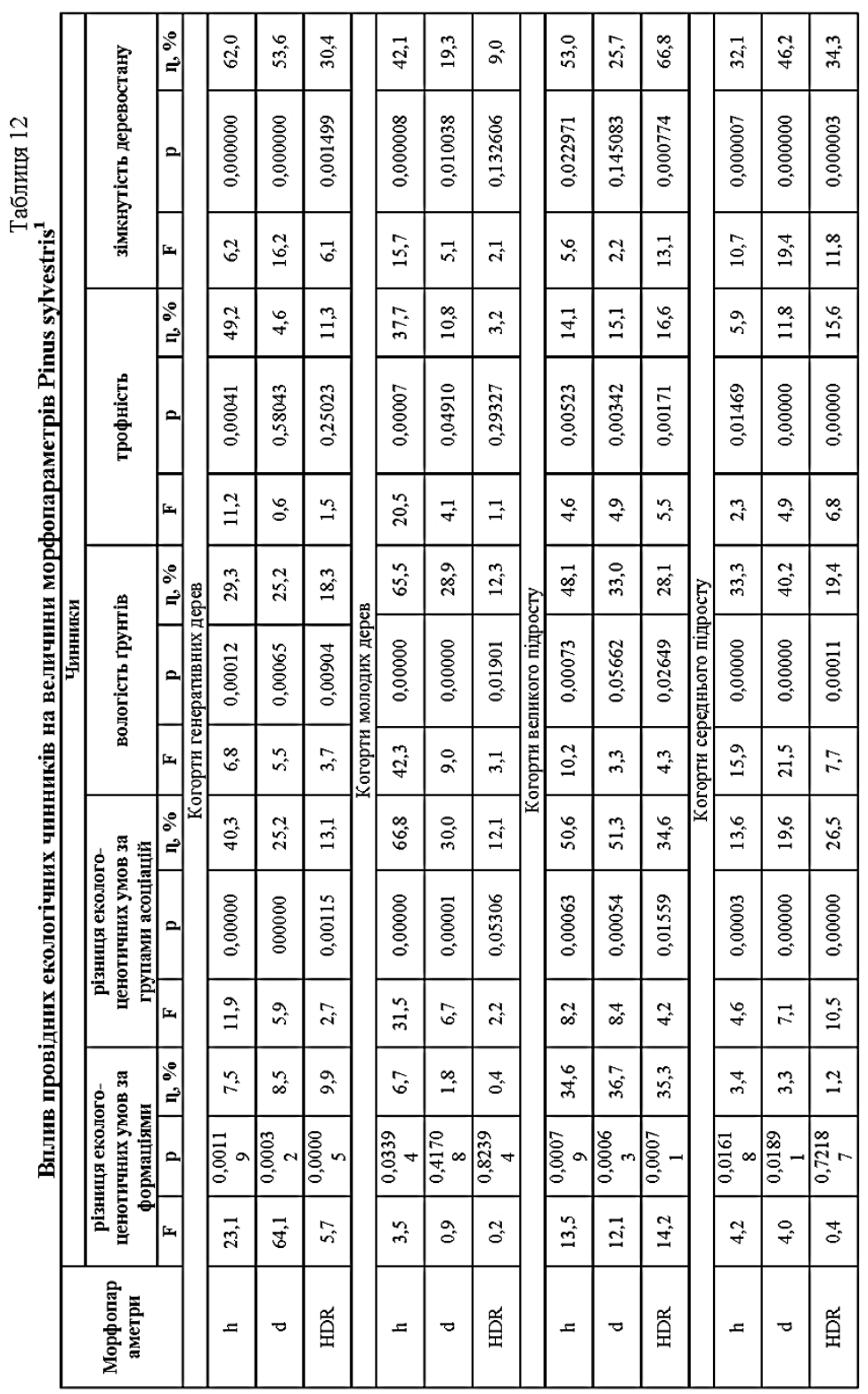




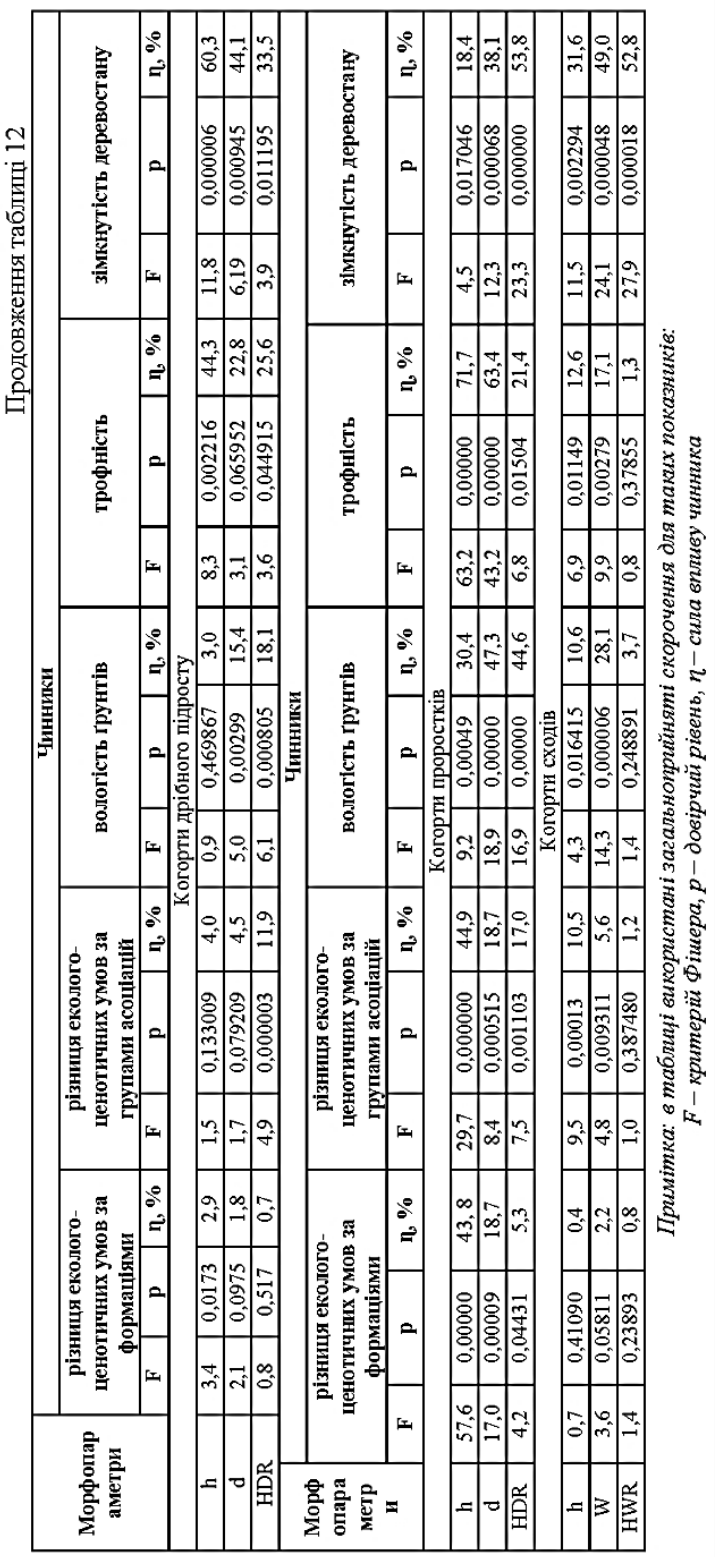




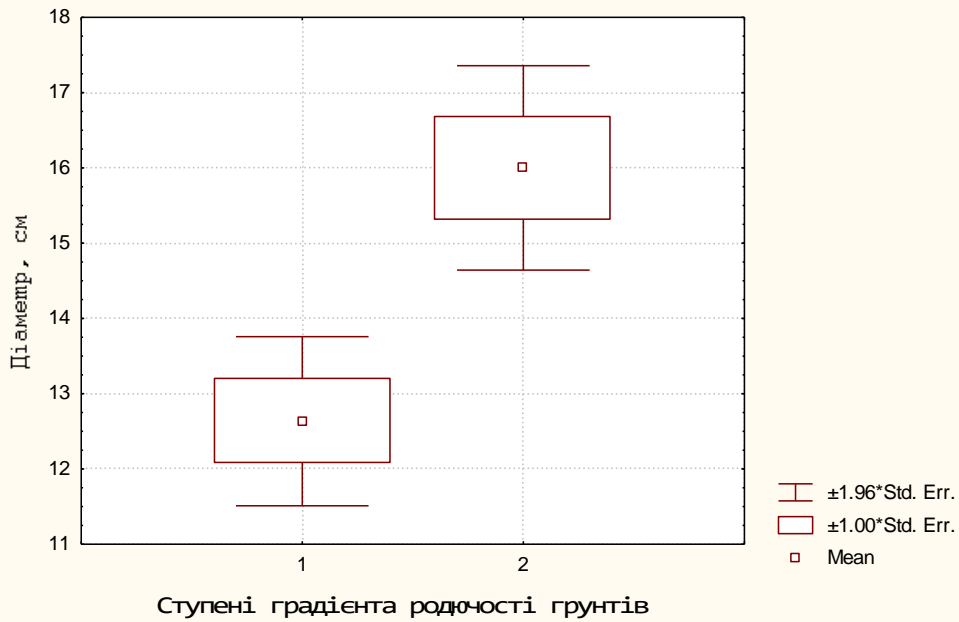

Рис. 2. Зміна величин діаметру стовбура у молодих дерев Pinus sylvestris за градієнтом родючості грунту; групи асоціацій, що відповідають ступеням градіснта: 1) Pineta (sylvestris) hylocomiosa; 2) Betuleta (pendulae) caricosa (pilosae)

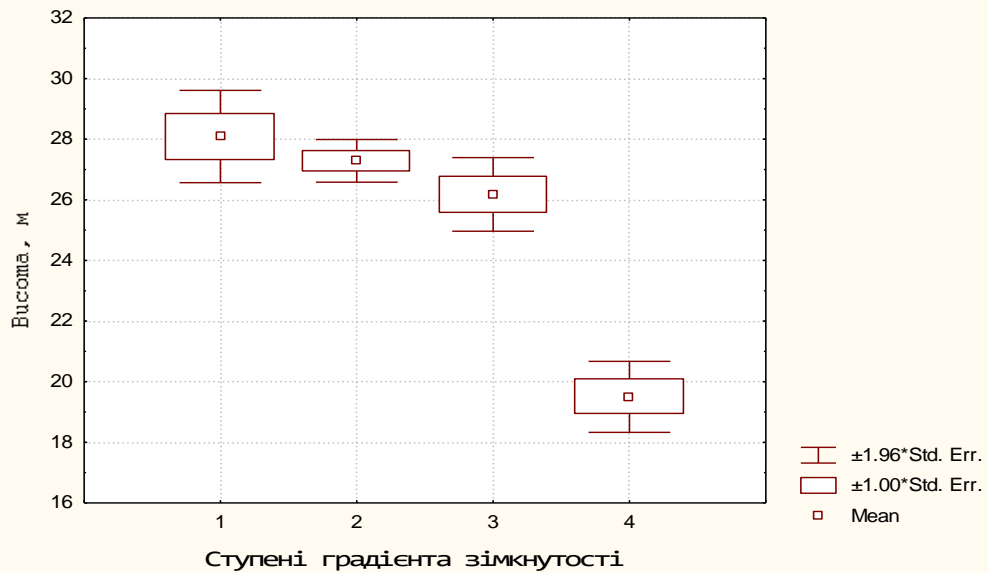

Рис. 3. Зміна висоти молодих дерев Pinus sylvestris за градіснтом зімкнутості ярусу деревостану; групи асоціацій, що відповідають ступеням градіснта: 1) Pineta (sylvestris) calamagrostidosa (epigeioris) (0,4); 2) Pineta (sylvestris) nardosa (strictae) $(0,5)$; 3) Pineta (sylvestris) hylocomiosa $(0,6)$; 4) Betuleto (penduli) - Pineta (sylvestris) vacciniosa (myrtilli) $(0,7)$ 


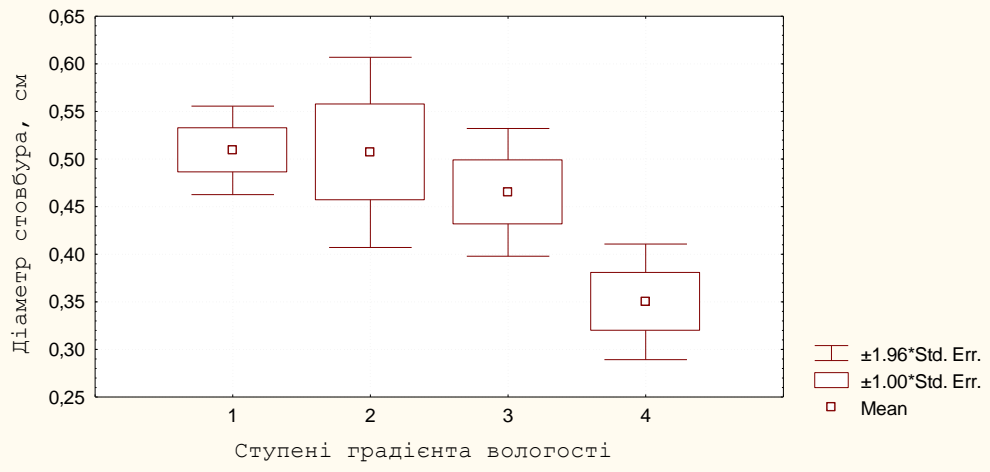

Рис. 4. Зміна величин діаметру у особин дрібного підросту Pinus sylvestris за градіснтом вологості грунтів; групи асоціацій, що відповідають ступеням градіснта: 1) Pineta (sylvestris) hylocomiosa; 2) Pineta (sylvestris) vacciniosa (myrtilli); 3) Pineta (sylvestris) franguloso (alni) - vacciniosa (myrtilli);

4) Pineta (sylvestris) sphagnosa

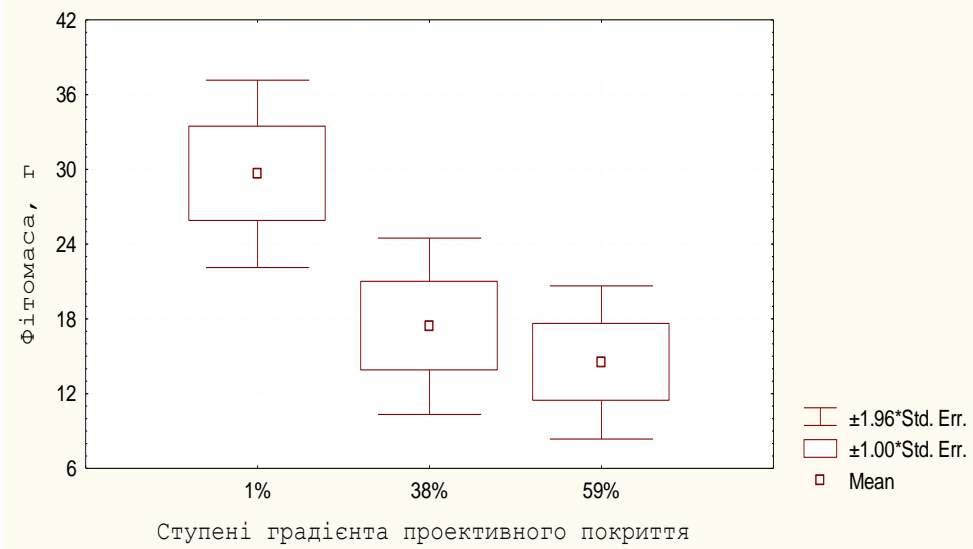

Рис. 5. Зміна значень фітомаси у дрібного підросту Pinus sylvestris за градіснтом просктивного покриття трав'яно-мохового покриву; угруповання, що відповідають ступеням градіснта: 1) Pinetum (sylvestris) hylocomiosum; 2) Pinetum (sylvestris) nardosum (strictae);

3) Pinetum (sylvestris) calamagrostidosum (epigeioris) 


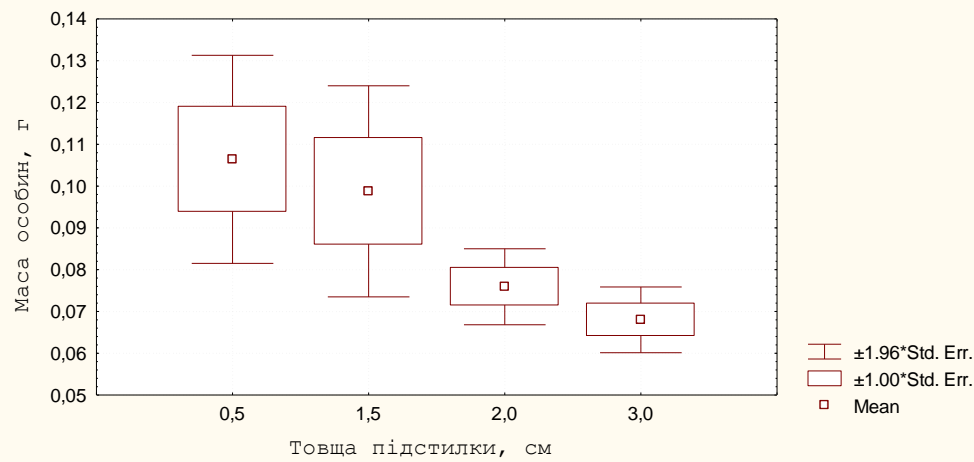

Рис. 6. Зміна маси сходів Pinus sylvestris за градіснтом товщі підстилки

Для материнського деревостану і когорт молодого покоління під час 3'ясування закономірностей формування розмірних параметрів особин провідних лісоутворювальних видів доцільно застосовувати не лише простий градієнтний аналіз, але й комплексний підхід. Останній може бути реалізований через оцінку зміни величин морфопараметрів за еколого-ценотичними умовами рослинних угруповань, груп асоціацій i навіть формацій рослинності. Здебільшого як під час застосування комплексного підходу, так i за простими градієнтами абіотичних екологічних чинників величини провідних морфопараметрів у лісоутворювальних видів змінювалися статистично достовірно $(\mathrm{p}<0,05)$. Переважно сила впливу окремо взятих екологічних факторів виявилась вищою, ніж сила впливу комплексу чинників.

Наведені відмінності у величині сили впливу різних екологоценотичних чинників на величини провідних морфопараметрів $\epsilon$ ще одним свідченням і відображенням реалізації лісоутворювальними видами різних типів популяційної поведінки. У конкурентних видів (P. sylvestris, $Q$. robur), конкурентно-толерантних (A. platanoides) більшу силу впливу мають окремо взяті абіотичні екологічні чинники, представлені на простих градієнтах. Для видів 3 реактивним (піонерним) типом популяційної поведінки (B. pendula, P. tremula), особливо їх підросту, навпаки, збільшується значущість комплексних еколого-ценотичних характеристик місцезростань. Це цілком закономірно, адже для появи й закріплення піонерних видів на нових територіях велике значення мають не лише параметри абіотичних умов середовища, але й наявність у їхніх межах рослинності та її стан. Також виду 3 найбільш чітко вираженими реактивними властивостями, яким $€ B$. Pendula, притаманні найвищі значення коефіцієнта варіації розмірних показників за групами асоціацій, які сягають 87,9\%. 
У результаті взаємодії біолого-екологічних властивостей видів із зовнішніми чинниками та індивідуального характеру реагування розмірних характеристик на зміну екологічних параметрів у різних місцезростаннях формуються особини, які мають відмінності в розмірних показниках, загалом специфічні ознаки морфології. При цьому велике значення має існування кореляцій між величинами морфопараметрів. У всіх лісоутворювальних видів достатньо високий рівень кореляційного зв'язку (переважно від $+0,67$ до $+0,91$ ) притаманний показникам висоти рослин та діаметру стовбура. Встановлено, що величина кореляцій не $\epsilon$ константною характеристикою: іiі розмір змінюється у процесі розвитку рослин і переходу їх з молодших когорт у старші. Трансформація кореляційних залежностей $є$ наслідком i відображенням різноманітності онтогенетичних тактик, що реалізуються різними видами на різних етапах розвитку, які, відповідно, посідають важливе місце у системі засобів, що забезпечують закріплення і виживання рослин у складі певних рослинних угруповань.

\section{ВИСНОВКИ}

Отже, ярусність лісових фітоценозів, довготривалість онтогенезу дерев та їхні морфологічні особливості виступають чинниками виокремлення в популяціях лісоутворювальних видів внутрішньопопуляційних груп рослин - когорт. Кожна 3 них характеризується певними величинами розмірних показників. Процес природного відновлення та формування деревостану з когорт молодого покоління $\epsilon$ поєднанням кількісних та якісних трансформацій у стані рослин i супроводжується їх послідовною зміною. Успішність, тривалість проходження кількісних і якісних змін суттєво залежать від впливу еколого-ценотичних чинників. У сприятливих екологічних умовах рослини швидше ростуть, набувають більшого розміру, що суттєво збільшує вірогідність переходу рослин із когорти в когорту та реалізацію успішного природного відновлення лісових фітоценозів.

\section{АНОТАЦІЯ}

У публікації представлено результати вивчення розмірних величин рослин провідних лісоутворювальних видів Лівобережного Полісся України (Pinus sylvestris L., Quercus robur L., Acer platanoides L., Betula pendula Roth., Populus tremula L.). Дослідженням охоплено лісові фітоценози, що є типовими для цього регіону. Вони належать до 42 асоціацій, 24 груп асоціацій та 4 формацій (Pineta sylvestris, Querceta roboris, Betuleta pendulae, Populeta tremulae) лісової рослинності. Робота базується на новітньому підході до поділу популяцій деревних рослин на внутрішньопопуляційні структурні групи - когорти. У його основу покладена прийнята в лісівництві методика реєстрації підросту і 
дерев, доповнена оцінкою розміру рослин, їх онтогенетичного стану й положення в архітектоніці лісової екосистеми. У складі популяцій провідних лісоутворювальних видів було виділено й вивчено сім когорт (від сходів до генеративних дерев ярусу деревостану). Доведено і на прикладі Pinus sylvestris детально проілюстровано, що когорти провідних лісоутворювальних видів Лівобережного Полісся України 3 різних угруповань, груп асоціацій, формацій статистично достовірно різняться за значеннями морфометричних показників. Відмінності у розмірних величинах проявляються вже на рівні сходів та проростків.

$\mathrm{У}$ когорт зазвичай має місце статистично достовірна $(\mathrm{p}<0,05)$ тенденція до збільшення величин статичних метричних показників за зростання родючості грунту. Значення цієї групи розмірних величин, навпаки, зменшувалися за збільшення проєктивного покриття нижніх ярусів лісу та зростання товщини підстилки. У всіх видів та когорт найбільші за розміром рослини формувалися у фітоценозах із зімкнутістю крон дерев 0,4-0,6. Найбільшими за розміром були особини 3 територій, які репрезентували свіжі або рідше вологі гігротопи. Несприятливими виступали як сухі, так і перезволожені місцезростання. У сходів $Q$. robur виявлено тісний, статистично достовірний кореляційний взаємозв'язок $(\mathrm{r}=$ 0,76) між масою жолудів та масою сходів.

Величини провідних морфопараметрів у когорт лісоутворювальних видів змінюються не тільки за простими, але й за комплексними еколого-ценотичними градієнтами. Встановлено, що на когорти молодого покоління видів, які за типом популяційної поведінки належать до конкурентних (Pinus sylvestris, Quercus robur) та толерантних (Acer platanoides), більшу силу впливу проявляють окремо взяті абіотичні екологічні чинники, представлені на простих градієнтах. У видів із реактивним (експлерентним) типом популяційної поведінки (Betula pendula, Populus tremula), навпаки, збільшується значущість комплексних еколого-ценотичних характеристик місцезростань.

\section{ЛITЕРАТУРА}

1. Кофман Г.Б., Кузьмичев В. В. Размерная структура древостоев: универсальность и единство. Эколого-географические аспекты лесообразовательного процесса. Красноярск : Институт леса Сибирского отделения РАН, 2009. С. 91-93.

2. Морозов Г.Ф. Учение о лесе. Москва : Гослесбумиздат, 1949. $456 \mathrm{c}$.

3. Пастернак П.С., Романов Н.В. Возобновление равнинных лесов Украинской ССР. Возобновление леса. Москва : Колос, 1975. C. 214-215.

4. Погребняк П.С. Основы лесной типологии. Киев : изд-во АН Украинской ССР, 1955. 455 с.

5. Санников С.Н., Санникова Н.С. Экология естественного возобновления сосны под пологом леса. Москва : Наука, 1985. 149 с. 
6. Ситник К.М. Збереження та відтворення лісових багатств України. Украӥнський ботанічний журнал. 2003. Т. 60. № 1. С. 3-5.

7. Скляр В.Г. Природне поновлення провідних лісоутворювальних видів Новгород-Сіверського Полісся: реалізовані екологічні ніші та їхня динаміка. Український ботанічний журнал. 2014. Т. 71. № 1. C. $8-16$.

8. Скляр В.Г., Злобін Ю.А. Внутрішньопопуляційна структура та методика їі вивчення у деревних лісоутворюючих видів. Чорноморський ботанічний журнал. 2013. Т. 9. № 3. С. 316-329.

9. Сукачев В.Н., Зонн С.В. Методические указания к изучению типов леса. Москва : АН СССР, 1961. 143 с.

10. Третьяков Н.В. Закон единства в строении насаджений. Новая деревня. Москва ; Ленинград, 1927. 113 с.

11. Шеляг-Сосонко Ю.Р. Екологічне та соціальне значення лісів. Менеджмент охоронних лісів України. Київ : Фитосоциоцентр, 2003. C. $10-23$.

12. Шеляг-Сосонко Ю.Р. Ліси України: біорізноманітність та збереження. Украӥнський ботанічний журнал. 2001. Т. 58. № 5. C. 519-529.

13. Connel J.H. Some processes affecting the species composition in forest gaps. Ecology. 1989. Vol. 70. № 3. P. 560-562.

14. McElwain J.C., Beerling D.J., Woodward F.I. Fossil plants and global warming at the triassic-jurassic boundary. Science. 1999. Vol. 285. № 5432. P. 1386-1390.

15. Skliar V., Sherstuk M. Size structure of phytopopulations and its quantitative evaluation. Eureka: Life Sciences. 2016. № 1. P. 9-15.

16. Skliar V.G. The dimensional characteristics of the middle undergrowth Quercus robur in forests of Novgorod-Sivers'k Polissia (Ukraine). European Applied Sciences. 2013. № 7. P. 19-20.

17. Ward J.S., Worthley T.E. Forest regeneration handbook. USA Forest N., E. Area, 2004. 44 p.

\section{Information about the authors:} Skliar V. H.,

Doctor of Biology, Professor, Head of the Department of Ecology and Botany Sumy National Agrarian University 160, Herasym Kondratiev str., Sumy, 40021, Ukraine

Melnychuk S. D., Doctor of Biology, Professor at the Department of Milk and Meat Technology Sumy National Agrarian University 160, Herasym Kondratiev str., Sumy, 40021, Ukraine 